\title{
Aloe arborescens and American cranberry (Vaccinium macrocarpon) extracts inhibit tumor-induced cutaneous angiogenesis in mice
}

\author{
PIOTR SKOPIŃSKII, ROBERT ZDANOWSKI², BARBARA JOANNA BAEAN", \\ ANDRZEJ KRZYSZTOF SIWICKI ${ }^{4}$, JANUSZ KOCIK' ${ }^{2}$, SŁAWOMIR LEWICKI ${ }^{2}$, MILENA SUSKA ${ }^{2}$, \\ KRZYSZTOF PASTEWKA ${ }^{5}$, EWA SKOPIŃSKA-RÓŻEWSKA ${ }^{6}$, URSZULA DEMKOW \\ ${ }^{1}$ Department of Histology and Embryology Center for Biostructure Research, Warsaw Medical University, Warsaw, Poland \\ ${ }^{2}$ Department of Regenerative Medicine, Military Institute of Hygiene and Epidemiology, Warsaw, Poland \\ ${ }^{3}$ Department of Immunology, Biochemistry and Nutrition, Warsaw Medical University, Warsaw, Poland \\ ${ }_{4}^{4}$ Department of Microbiology and Clinical Immunology, Warmian-Mazurian University, Olsztyn, Poland \\ ${ }^{5}$ Department of Urology, Postgraduate Medical Center, Warsaw, Poland \\ ${ }^{6}$ Pathology Department, Center for Biostructure Research, Warsaw Medical University, Warsaw, Poland \\ ${ }^{7}$ Department of Laboratory Diagnostics and Clinical Immunology of the Developmental Age, Warsaw Medical University, Warsaw, Poland
}

\begin{abstract}
Research in cancer control indicates the importance of adjuvant and complementary therapies. Medicinal plants are a rich source of substances that might be used for this purpose. Aloe vera (Aloe arborescens, Aloe barbadensis Mill) plants are succulents belonging to the Lillacea family. Aloe leaves contain many physiologically active substances with indirect and direct anti-tumor activity etc. Cranberries are a group of evergreen plants in the subgenus Oxycoccus of the genus Vaccinium. Anticancer properties of cranberries were also described, hypothetically connected to their potential antiangiogenic activity. The aim of the present study was to evaluate the in vivo effect of three commercially available preparations of the aforementioned plants on the neovascular reaction observed after intradermal injection of syngeneic sarcoma or xenogeneic (human) lung and kidney cancer cells. We have shown that, additionally to their immunostimulatory properties, Aloe and cranberry preparations behave as tumor angiogenesis inhibitors. We also present a tumor-induced cutaneous angiogenesis (TIA) test as a valuable method for in vivo quantitative evaluation of activity of various anti-angiogenic compounds. As the extension of these studies it would be prudent to compare antiangiogenic potential of the assessed preparations with antiangiogenic compounds with clinically confirmed anticancer efficiency. It would facilitate reasoning about potential efficiency of these plant extracts, particularly in immunocompromised cancer patients, complementary to their standard therapies.
\end{abstract}

Key words: Aloe arborescens, cranberry, mice, tumors, angiogenesis.

(Centr Eur J Immunol 2013; 38 (4): 480-485)

\section{Introduction}

Aloe vera (Aloe arborescens, Aloe barbadensis Mill) plants are succulents belonging to the Lillacea family, perennial herbs probably native to North Africa and naturalized in most warmer areas of the world. Now they are cultivated in many countries, including Poland. Aloe leaves contain many physiologically active substances with immunomodulatory, antimicrobial, anti-inflammatory and wound-healing properties, belonging to glycoproteins, anthraquinones, polysaccharides and low-molecular-weight species [1]. Some of these compounds also presented in- direct and direct anti-tumor activity [2-7]. It was reported in experiments on mice implanted with sarcoma cells that Aloe polysaccharides between 400 and 5 KDa molecular size exhibited the most potent antitumor activity in vivo and in vitro [8]. Whether anticancer properties might be partly dependent on tumor angiogenesis inhibition is not clarified since Aloe contains both angiogenic and anti-angiogenic factors [9-12].

Cranberries are a group of evergreen plants in the subgenus Oxycoccus of the genus Vaccinium. Traditionally the cranberry was used by the Native Americans as a food source and medicinally to treat wounds, urinary disorders,

Correspondence: Sławomir Lewicki, PhD, Department of Regenerative Medicine, Military Institute of Hygiene and Epidemiology, Kozielska 4, 01-163 Warsaw, Poland, e-mail: lewickis@ gmail.com 
diarrhea, and diabetes. Cranberries contain a lot of active substances with immunotropic, antioxidant and anti-inflammatory properties. Anticancer properties of cranberries were also described. They contain 3 classes of flavonoids (flavonols, anthocyanins, and proanthocyanidins), catechins, hydroxycinnamic and other phenolic acids, and triterpenoids. Characterization of an active subfraction of proanthocyanidins revealed the presence of dimers and oligomers of catechin-epicatechin, monomeric catechins, and quercetin glycosides. The major anthocyanins found in cranberry are galactosides and arabinosides of cyanidin and peonidin. The fruits and their preparations (juices, extracts) exhibit high antioxidant properties due to substantial flavonoid and phenolic acids content. It has been demonstrated that cranberries inhibit oxidative and inflammatory damage to the vascular endothelium, oxidative processes including oxidation of low-density lipoproteins, and oxidative damage to rat neurons during simulated ischemia [13-18].

It was suggested that anti-tumor effect of cranberries administration might be partly connected with their antiangiogenic activity. Ability of anthocyanins, proanthocyanidins, quercetin and triterpene acids to inhibit angiogenesis as well as tumor progression and metastasis was reported [19-25].

The aim of the present study was to evaluate the in vivo effect of three commercially available preparations Aloe extract Biostymina, Aloe + formula Bioaron C, and cranberry extract $\dot{Z}$ urawit - on the neovascular reaction observed in Balb/c mice skin 3 days after intradermal injection of syngeneic L-1 sarcoma or xenogeneic (human) lung and kidney cancer cells.

\section{Material and methods}

\section{Drugs}

Biostymina (Aloe aborescentis extractum fluidum, Phytopharm Klęka SA) amp. $1 \mathrm{ml}$. Each ampoule contains an aqueous extract $(1: 4)$ from fresh leaves.

Bioaron C syrup, Phytopharm, Klęka SA (100 ml contains: Extractum Aloe arborescentis recens fluidum 38.4 g, Vitaminum C - 1.02 g, Aroniae melanocarpae succus $-23.3 \mathrm{~g}$ ).

Żurawit 25 : 1 (Herbapol Lublin) caps. $0.5 \mathrm{ml}$. Each capsule contains $220 \mathrm{mg}$ of Vaccinium macrocarpon (American cranberry) extract obtained from $5500 \mathrm{mg}$ of cranberries.

\section{Mice}

The study was performed on 20-22 $\mathrm{g}$ of body mass female, 8-10-weeks old inbred Balb/c mice delivered from the Polish Academy of Sciences. For all performed experiments, animals were handled according to the Polish law on the protection of animals and NIH (National Institutes of Health) standards. Mice were housed 4-5 per cage and maintained under conventional conditions (room temperature $22.5-23.0^{\circ} \mathrm{C}$, relative humidity $50-70 \%, 12 \mathrm{~h}$ day/night cycle) with free access to standard rodent diet and water.

All experiments were accepted by the local Ethical Committee.

\section{Sarcoma L-1 (syngeneic tumor)}

L-1 Sarcoma cells from in vitro culture stock were delivered from the Warsaw Oncology Center collection thanks to dr Henryk Skurzak and passaged in vivo on syngeneic Balb/c mice. Briefly, sarcoma cells were grafted $\left(10^{6} / 0.1 \mathrm{ml}\right)$ subcutaneously into mouse sub-scapular region. After 14 days the tumor was excised, cut to smaller pieces, rubbed through stainless sieve and suspended in $5 \mathrm{ml}$ of PBS. The suspension was left for $10 \mathrm{~min}$ at room temperature. After sedimentation the supernatant was collected and centrifuged for $10 \mathrm{~min}$ at $300 \mathrm{~g}$. Obtained sarcoma cells were washed once with PBS for $10 \mathrm{~min}$, then centrifuged at $300 \mathrm{~g}$, and resuspended in Parker medium in concentration of $4 \times 10^{6} / \mathrm{ml}$. Viability of tumor cells suspension as assessed by trypan blue exclusion test was about $90 \%$.

\section{Human lung cancer}

Pulmonary tumor (squamous-cell carcinoma) was obtained from the Surgery Department of the Institute of Tuberculosis and Lung Diseases thanks to professor Tadeusz Orłowski, and was prepared as previously described [26]. Briefly, tumor tissue was sliced in a sterile ice-cold PBS, then treated with an enzyme cocktail containing collagenase $0.1 \mathrm{mg} / \mathrm{ml}$ and DNA-se $0.004 \mathrm{mg} / \mathrm{ml}$, at room temperature, and stirred for $45 \mathrm{~min}$. Then, the obtained suspension was filtered through a sieve, washed twice in PBS (10 $\min 300 \times \mathrm{g})$ and suspended in Parker culture medium at a concentration of $5 \times 10^{6}$ cells per ml. Viability of tumor cell suspensions as assessed by trypan blue exclusion test was about $85 \%$.

\section{Human kidney cancer}

Kidney tumor (Carcinoma clarocellulare) was obtained surgically from the Department of Urology, Postgraduate Medical Center. $2.5 \mathrm{~g}$ of tissue were suspended in $5 \mathrm{ml}$ of phosphate-buffered saline (PBS), homogenized with an ultrasonic disrupter VirSonic (Virtis) for 2 minutes, at frequency $22.5 \mathrm{KHz}$ and stored at $-70^{\circ} \mathrm{C}$, in $1 \mathrm{ml}$ aliquots.

\section{Tumor-induced angiogenesis test (TIA)}

Multiple $0.05 \mathrm{ml}$ samples of homogenate or cell suspension were injected intradermally into partly shaved, narcotised Balb/c mice (3-4 mice per group, 3-6 injections per mouse). In order to facilitate the localisation of injection sites later on, the suspension was coloured with $0.1 \%$ 
Table 1. Statistical analysis of the results presented in Figure 1

\begin{tabular}{|c|c|c|c|c|}
\hline Tukey's Multiple Comparison Test & Mean Diff. & $\mathbf{q}$ & Significant? & $P<0.05 ?$ \\
\hline control vs. aloe extract $2 \mu \mathrm{l}$ & 3.400 & 13.81 & yes & $* * *$ \\
\hline control vs. aloe extract $4 \mu \mathrm{l}$ & 4.400 & 17.51 & yes & $* * *$ \\
\hline control vs. aloe extract $8 \mu \mathrm{l}$ & 4.100 & 16.65 & yes & $* * *$ \\
\hline aloe extract $2 \mu \mathrm{l}$ vs. aloe extract $4 \mu \mathrm{l}$ & 1.000 & 3.858 & yes & $*$ \\
\hline aloe extract $2 \mu \mathrm{l}$ vs. aloe extract $8 \mu \mathrm{l}$ & 0.7000 & 2.752 & no & NS \\
\hline aloe extract $4 \mu \mathrm{l}$ vs. aloe extract $8 \mu \mathrm{l}$ & -0.3000 & 1.157 & no & ns \\
\hline
\end{tabular}

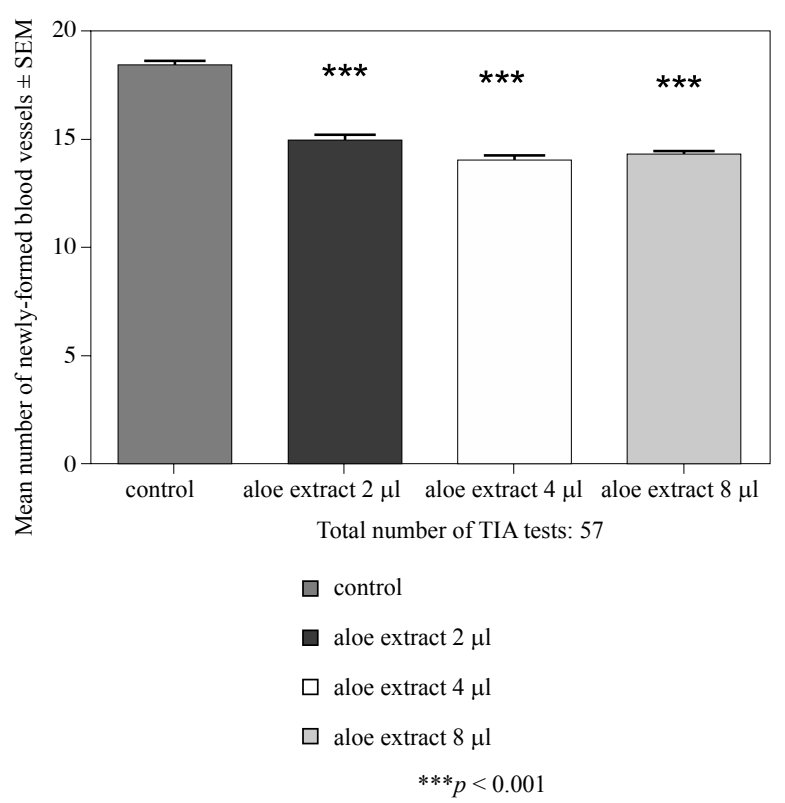

Fig. 1. Results of experiments performed with Biostymina and human lung cancer cells. Mice were given the drug for 3 days after cells grafting

of trypan blue. On the day of grafting and on the following two days mice were fed by Eppendorf pipette with tested substances, or water as a control. In the experiment with Bioaron C, another control group of mice was fed with placebo-syrup containing aroniae and vitamin $\mathrm{C}$ only. After 72 hours mice were sacrificed with lethal dose of Morbital. All newly formed blood vessels were identified and counted in dissection microscope, on the inner skin surface, at magnification of $6 \times$, in $1 / 3$ central area of microscopic field. Identification was based on the fact that new blood vessels are thin, directed to the point of cells injection, with ramifications, and some of them are tortuous.

All experiments were performed in anaesthesia: $3.6 \%$ chloral hydrate, $0.1 \mathrm{ml}$ per $10 \mathrm{~g}$ of body mass (Sigma); ketamine $100 \mathrm{mg} / \mathrm{kg}$ and xylazine $10 \mathrm{mg} / \mathrm{kg}$ (BIOWET, Puławy, Poland).

Statistical evaluation of the results was performed by unpaired $t$ test and one-way ANOVA, and the signifi- cance of differences between the groups was verified with a Tukey's Multiple Comparison Test (GraphPadPrism).

\section{Results}

The effect of the aloe extract (biostymina) on the development of cutaneous angiogenesis reaction after grafting of human pulmonary squamous cancer cells is presented in Fig. 1 and Table 1. All doses of the remedy highly significantly diminished number of newly-formed blood cells in comparison to the control $(p<0.001)$.

The results of experiments on the effect of Bioaron $\mathrm{C}$ on cutaneous angiogenesis induced by grafting of human kidney cancer homogenate are presented graphically in Fig. 2 and their statistical analysis in Table 2. Bioaron $\mathrm{C}$ highly significantly diminished the number of newly-formed blood vessels in comparison to the control $(p<0.001)$ and to placebo $(p<0.01)$. No inhibitory effect was observed for placebo (syrup without aloe extract) in comparison to the control (water).

The effect of the cranberry extract (Źurawit) on the development of cutaneous angiogenesis reaction after grafting of L-1 sarcoma cells is presented in Fig. 3 and in Table 3. Feeding of recipient mice with this remedy, for 3 days after tumor cells grafting, highly significantly diminished the number of newly-formed blood vessels in comparison to the control $(p<0.0001)$.

\section{Discussion}

Research in cancer control indicates the importance of complementary therapies. Medicinal plants are a rich source of substances which might be used for this purpose. Among them Aloe vera and its active compounds are of special interest. It was reported that in mice, Aloe and its compounds are effective radioprotective agents, what can be useful in increasing the tolerance dose of radiation in cancer patients [27]. In rats, oral administration of Aloe vera and honey reduced Walker tumor growth by decreasing cell proliferation and increasing apoptosis in tumors [28]. Other authors demonstrated beneficial effects of Aloe emodin, hydroxyanthraquinone compound, on proliferation and differentiation of highly metastatic B16-F10 melanoma 
Table 2. Statistical analysis of the results presented in Figure 2

\begin{tabular}{lcccc}
\hline Tukey's Multiple Comparison Test & Mean Diff & q & Significant? & $\boldsymbol{P}<\mathbf{0 . 0 5 ?}$ \\
\hline control vs. aronia + vit. C & 0.9000 & 3.104 & No & NS \\
\hline control vs. Bioaron C & 2.500 & 8.825 & Yes & $* * *$ \\
\hline aronia + vit. C vs. Bioaron C & 1.600 & 5.417 & Yes & $* *$ \\
\hline
\end{tabular}

murine cells [29]. Chen et al. reported that in vitro emodin, aloe-emodin and rhein induced DNA damage followed by the inhibition of DNA repair-associated gene expression in SCC-4 human tongue cancer cells [30]. Three anthraquinones (aloesin, aloe-emodin and barbaloin) and $\mathrm{N}$-terminal octapeptide derived from verectin, a biologically active 14 $\mathrm{kDa}$ glycoprotein extracted from Aloe vera leaves, exerted chemopreventive effect through modulating antioxidant and detoxification enzyme activity levels in various human cancer cell lines in vitro. In vivo, these compounds exhibited significant prolongation of the life span of tumor-transplanted animals (Ehrlich ascites carcinoma) [31].

Recently, it has been reported that in human healthy volunteers, a combination of vitamin $\mathrm{C}$ and Aloe vera juice significantly increased, in vitro and ex vivo, NK cells cytotoxicity against K562 cancer cell line [32].

Our earlier studies have revealed a stimulatory effect of Biostymina, water soluble extract of the leaves of triennial plants Aloe arborescens Mill., and Bioaron C, herbal syrup containing Biostymina, Aronia melanocarpa water extract, and ascorbic acid, on cellular and humoral immunity in mice $[33,34]$. Other authors performed clinical evaluation of the efficacy and safety of Bioaron $C$ in children with recurrent bacterial and viral infections of the upper respiratory tract [35]. Fourteen days' preventive application of Bioaron $\mathrm{C}$ in these children was associated with the reduction of infection incidence in this group. The immunomodulatory effect of the drug depended on the baseline condition and was manifested by the effect on T cell immunity and the phagocytic activity of the neutrophils.

Recently, other authors have reported anti-viral activity of these herbal drugs [36]. In this paper we present evidence that, additionally to their immunostimulatory properties, Biostymina and Bioaron $\mathrm{C}$ behave as tumor angiogenesis inhibitors what would be of great value in

Table 3. Statistical analysis of the results presented in Figure 3

\begin{tabular}{lc}
\hline Unpaired $t$ test \\
\hline$p$ value $<0.0001$ & $* * * *$ \\
\hline$p$ value summary & Yes \\
\hline Are means significantly different $(p<0.05)$ & Two-tailed \\
\hline One- or two-tailed $p$ value? & $\mathrm{t}=8.256, \mathrm{df}=22$ \\
\hline $\mathrm{t}, \mathrm{df}$
\end{tabular}

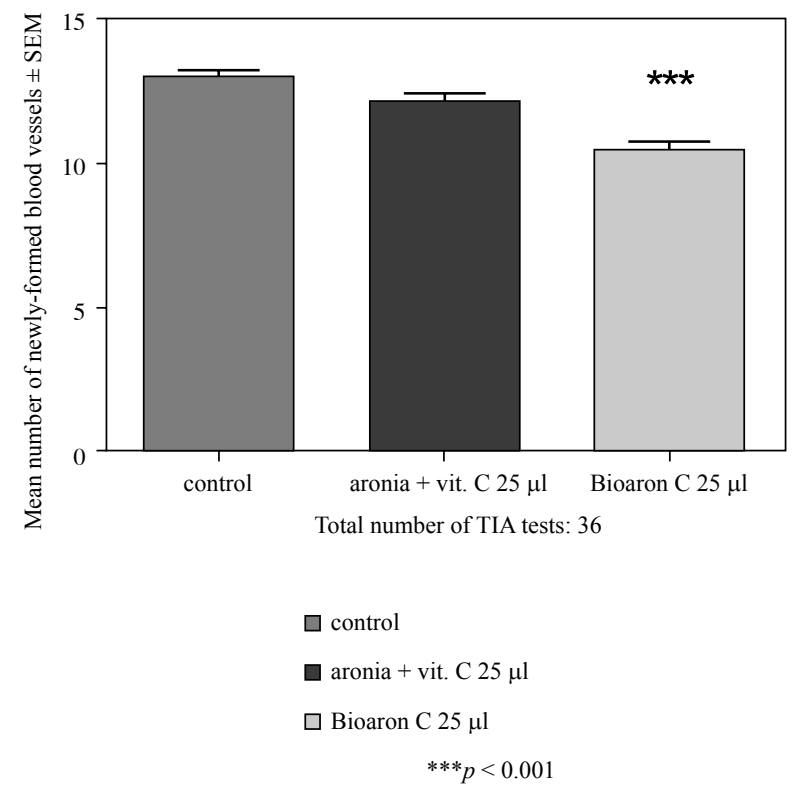

Fig. 2. Results of experiments performed with Bioaron C and human kidney cancer homogenate. Mice were given the drug for 3 days after tumor grafting

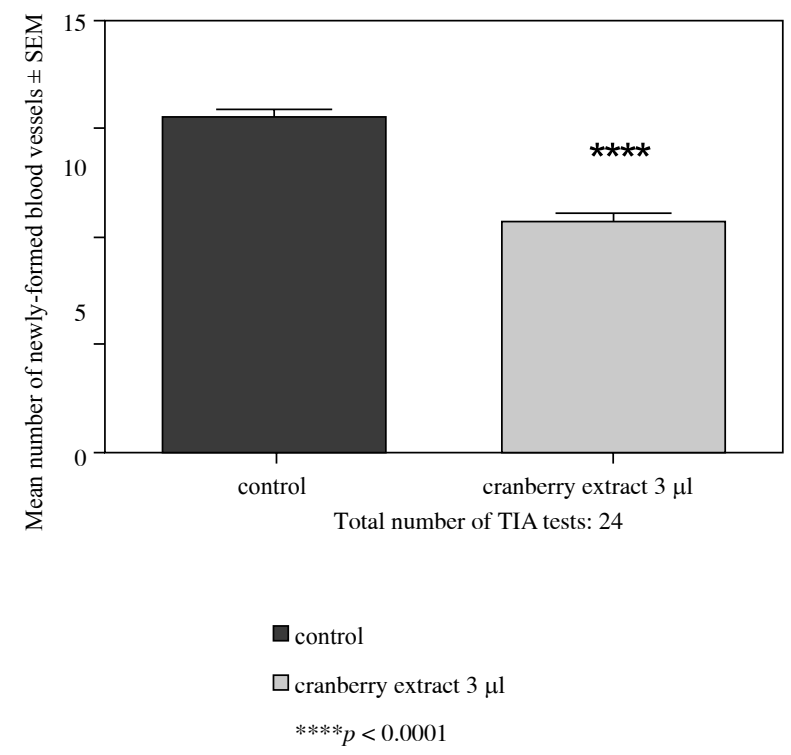

Fig. 3. Results of experiments performed with Żurawit and syngeneic for Balb/c mice tumor L-1 sarcoma. Mice were given the remedy for 3 days after tumor cells grafting 
additional therapy of patients with tumors, especially immunocompromised after standard treatment.

In this paper we also present the results of our preliminary studies on the effect of the cranberry extract Żurawit on the early neovascular reaction to syngeneic tumor cells transplantation. The cranberry extract administered to recipient mice for three days significantly diminished the number of newly-formed blood vessels in the place of intradermal tumor cells injection.

It was repeatedly reported that compounds found in cranberries showed a high anticancer activity with different mechanisms of action. The total polyphenol extract inhibited proliferation of colon (HT-29, HCT-116, SW480, SW620), oral (CAL27, KB) and prostate cancer cell lines (RWPE-1, RWPE-2, 22Rv1) [37]. Pentacyclic triterpenoid ursolic acid found in the peel of cranberry fruit inhibited growth of several cancer cell lines [24, 38]. It has also been demonstrated that ursolic acid inhibited HT-29 cancer cell line growth more effectively than the cranberry proanthocyanidin fraction did [39]. Additional triterpene hydroxycinnamates (identified by HPLC and NMR as cis(1) and trans- (2) isomers of 3-O-p-hydroxycinnamoyl ursolic acid) isolated from whole cranberry fruit have shown a higher antiproliferative activity in MCF-7 breast, ME180 cervical and PC3 prostate tumor cell lines than quercetin or cyanidin-3-galactoside [38].

Resveratrol, epigallocatechin gallate, and quercetin (a major flavonoid in cranberry fruit) are capable to induce apoptosis in cancer cells [39-44].

A large group of anticancer properties of cranberries is associated with their antiangiogenic activity. Researchers repeatedly proven that anthocyanins, proanthocyanidins, ursolic acid, quercetin and triterpene acids have an antiangiogenic activity, and inhibit tumor progression and metastasis.

A cranberry extract in human keratinocytes inhibited the expression of VEGF induced by hydrogen peroxide or TNF- $\alpha$ Antiangiogenic activity of the cranberry extract was also observed in studies of the tumor endothelial cell line (EOMA) originating from a developing tumor hemangioma in children. The cranberry extract inhibited transcription of MCP-1, factor produced by macrophages, which stimulates angiogenesis. In mice with melanoma, ursolic acid reduced the levels of VEGF, nitric oxide and proinflammatory cytokines and increased the levels of tissue inhibitor of metalloproteinase (TIMP1) and interleukin 2 (IL-2) in serum [19-25, 45-47].

Our studies confirm the anti-angiogenic effect of the cranberry extract. Additionally, we present tumor-induced cutaneous angiogenesis (TIA) test as a valuable method, which may be used in further studies for in vivo quantitative evaluation of activity of various anti-angiogenic compounds present in cranberries and their extracts.

The authors certify that there is no conflict of interest with any financial organization regarding the material discussed in the manuscript.

\section{References}

1. Choi S, Chung M-H (2003): A review on the relationship between Aloe vera components and their biologic effects. Semin Integr Med 1: 53-62.

2. Akev N, Turkay G, Can A, et al. (2007): Tumour preventive effect of Aloe vera leaf pulp lectin (Aloctin I) on Ehrlich ascites tumours in mice. Phytother Res 2: 1070-1075.

3. Liu C, Leung MY, Koon JC, et al. (2006): Macrophage activation by polysaccharide biological response modifier isolated from Aloe vera L. var. Chinensis (Haw.) Berg. Int Immunopharmacol 6: 1634-1641.

4. Talmadge J, Chavez J, Jacobs L, et al. (2004): Fractionation of Aloe vera L. inner gel, purification and molecular profiling of activity. Intern Immunopharmacol 4: 1757-1773.

5. Peng SY, Norman J, Curtin G, et al. (1991): Decreased mortality of Norman murine sarcoma in mice treated with the immunomodulator, Acemannan. Mol Biother 3: 79-87.

6. Lin ML, Lu YC, Chung JG, et al. (2010): Aloe-emodin induces apoptosis of human nasopharyngeal carcinoma cells via caspase- 8 - mediated activation of the mitochondrial death pathway. Cancer Lett 291: 46-58.

7. Chiu TH, Lai WW, Hsia TC, et al. (2009): Aloe-emodin induces cell death through S-phase arrest and caspase-dependent pathways in huiman tongue squamous cancer SCC-4 cells. Anticancer Res 29: 4503-4511.

8. Im SA, Oh ST, Song S, et al. (2005): Identification of optimal molecular size of modified Aloe polysaccharides with maximum immunomodulatory activity. Int Immunopharmacol 5: 271-279.

9. Cardenas C, Quesada AR, Medina MA (2006): Evaluation of the anti-angiogenic effect of aloe-emodin. Cell Mol Life Sci 63: 3083-3089.

10. Moon EJ, Lee YM, Lee OH, et al. (1999): A novel angiogenic factor derived from Aloe vera gel: beta sitosterol, a plant sterol. Angiogenesis 3: 119-123.

11. Lee MJ, Lee OH, Yoon SH, et al. (1998): In vitro angiogenic activity of Aloe vera gel on calf pulmonary artery endothelial cells. Arch Pharm Res 21: 260-265.

12. Barrantes E, Guinea M (2003): Inhibition of collagenase and metalloproteinases by aloins and aloe gel. Life Sci 72: 843850 .

13. Neto CC, Krueger CG, Lamoureaux TL, et al. (2006): MALDI-TOF MS characterization of proanthocyanidins from cranberry fruit (Vaccinium macrocarpon) that inhibit tumor cell growth and matrix metalloproteinase expression in vitro. J Sci Food Agric 86: 18-25.

14. Fuleki T, Francis FJ (1968): Quantitative methods for anthocyanins. Purification of cranberry anthocyanins. J Food Sci 33: 266-269.

15. Vinson JA, Su X, Zubik L, Bose P (2001): Phenol antioxidant quantity and quality in foods: fruits. J Agric Food Chem 49: 5315-5321.

16. Neto CC, Sweeney-Nixon MI, Lamoureaux TL, et al. (2005): Cranberry phenolics: effects on oxidative processes, neuron cell death and tumor cell growth. In: Shahidi F, Ho C-T (eds.). Symposium Series No. 909: Phenolic Compounds in Foods and Natural Health Products Columbus, OH: ACS Books; 271-282.

17. Yan X, Murphy BT, Hammond GB, et al. (2002): Antioxidant activities and antitumor screening of extracts from cranberry fruit (Vaccinium macrocarpon). J Agric Food Chem 50: 5844-5849. 
18. Youdim KA, McDonald J, Kalt W, Joseph JA (2002): Potential role of dietary flavonoids in reducing microvascular endothelium vulnerability to oxidative and inflammatory insults. J Nutr Biochem 13: 282-288.

19. Bagchi D, Sen CK, Bagchi M, Atalay M (2004): Anti-angiogenic, antioxidant and anticarcinogenic properties of novel anthocyanin-rich berry extract formula. Biochemistry 69 : 75-80.

20. Cardenas C, Quesada AR, Medina MA (2004): Effects of ursolic acid on different steps of the angiogenic process. Biophem Biophys Res Commun 320: 402-408.

21. Donnini S, Finetti F, Lusini L, et al. (2006): Divergent effects of quercetin conjugates on angiogenesis. Br J Nutr 95: 1016-1023.

22. Kanjoormana M, Kuttan G (2010): Anti-angiogenic activity of ursolic acid. Integr Cancer Ther 9: 224-235.

23. Kim MH (2003): Flavonoids inhibit VEGF/bFGF - induced angiogenesis in vitro by inhibiting the matrix - degrading proteases. J Cell Biochem 89: 529-538.

24. Kondo M, MacKinnon SL, Craft CC, et al. (2011): Ursolic acid and its esters: occurrence in cranberries and other Vaccinium fruit and effects on matrix metalloproteinase activity in DU145 prostate tumor cells. J Sci Food Agric 91: 789-796.

25. Kim KK, Singh AP, Singh RK, et al. (2012): Anti-angiogenic activity of cranberry proanthocyanidins and cytotoxic properties in ovarian cancer cells. Int J Oncol 40: 227-235.

26. Skopinska-Różewska E, Piazza GA, Sommer E, et al. (1998): Inhibition of angiogenesis by sulindac and its sulfone metabolite (FGN-1): a potential mechanism for their antineoplastic properties. Int J Tissue React 20: 85-89.

27. Saini DK, Saini MR (2011): Evaluation of radioprotective efficacy and possible mechanism of action of Aloe gel. Environm Toxicol Pharmacol 31: 427-435.

28. Tomasin R, Gomes-Marcondes MC (2011): Oral administration of Aloe vera and honey reduces Walker tumour growth by decreasing cell proliferation and increasing apoptosis in tumor tissue. Phytother Res 25: 619-623.

29. Tabolacci C, Lentini A, Mattioli P, et al. (2010): Antitumor properties of aloe-emodin and induction of transglutaminase 2 activity in B16-F10 melanoma cells. Life Sci 87: 316-324.

30. Chen YY, Chiang SY, Lin JG, et al. (2010): Emodin, aloe-emodin and rhein induced DNA damage and inhibited DNA repair gene expression in SCC-4 human tongue cancer cells. Anticancer Res 30: 945-951.

31. El-Shemy HA, Aboul-Soud MA, Nassr-Allah AA, et al. (2010): Antitumor properties and modulation of antioxidant enzymes activity by Aloe vera leaf active principles isolated via supercritical carbon dioxide extraction. Curr Med Chem 17: 129-138.

32. Toliopoulos I, Simos Y, Verginadis I, et al. (2012): NK cell stimulation by administration of vitamin $\mathrm{C}$ and Aloe vera juice in vitro and in vivo: a pilot study. J Herbal Med 2: 29-33.

33. Białas-Chromiec B, Skopińska-Różewska E, Strzelecka H, et al. (2000): The immunomodulatory effect of Biostimine - water soluble extract of the leaves of triennial plants Aloe arborescens Mill. Oncol Pol 3: 85-89.

34. Skopińska-Różewska E, Wasiutyński A, Skopiński P, et al. (2011): In vivo effect of two complex herbal remedies Echinasal and Bioaron $\mathrm{C}$ on antibody production and immunological angiogenesis in mice. Centr Eur J Immunol 36: 139-144.

35. Horoszkiewicz-Hassan M, Beuscher N, Lehnfeld R, et al. (2005): The tolerance and efficacy of Bioaron C syrup in the treatment of upper respiratory tract infections in children. Herba Polonica 5: 45-54.

36. Glatthaar-Saalmuller B, Michalak A, Bastian P, Fal AM (2012): In vitro evaluation of antiviral activity of Biostymina and Bioaron $\mathrm{C}$ against human pathogenic virus: rhinovirus type 14 (HRV14). Postępy Fitoterapii 3: 156-161.

37. Seeram NP, Adams LS, Hardy ML, Heber D (2004): Total cranberry extract vs. its phytochemical constituents: antiproliferative and synergistic effects against human tumor cell lines. J Agric Food Chem 52: 2512-2517.

38. Murphy BT, MacKinnon SL, Yan X, et al. (2003): Identification of triterpene hydroxycinnamates with in vitro antitumor activity from whole cranberry fruit (Vaccinium macrocarpon). J Agric Food Chem 51: 3541-3545.

39. Liberty AM, Hart P, Neto CC. Ursolic acid and proanthocyanidins from cranberry (Vaccinium macrocarpon) inhibit tumor colony formation and proliferation in HCT-116 and HT-29 colon tumor cells. Annual Meeting of the American Society of Pharmacognosy, Washington, DC 2006.

40. Choi J, Kim J, Lee J, et al. (2001): Induction of cell cycle arrest and apoptosis in human breast cancer cells by quercetin. Int J Oncol 19: 837-844.

41. Ferguson PJ, Kurowska EM, Freeman DJ, et al. (2006): In vivo inhibition of growth of human tumor lines by flavonoid fractions from cranberry extract. Nutr Cancer 56: 86-94.

42. Ferguson PJ, Kurowska EM, Freeman DJ, et al. (2004): A flavonoid fraction from cranberry extract inhibits proliferation of human tumor cell lines. J Nutr 134: 1529-1535.

43. Lee LT, Huang YT, Hwang JJ, et al. (2002): Blockade of the epidermal growth factor receptor tyrosine kinase activity by quercetin and luteolin leads to growth inhibition and apoptosis of pancreatic tumor cells. Anticancer Res 22: 1615-1627.

44. Ramos S, Alia M, Bravo L, Goya L (2005): Comparative effects of food-derived polyphenols on the viability and apoptosis of a human hepatoma cell line (HepG2). J Agric Food Chem 53: 1271-1280.

45. Kiran MS, Viji RI, Sameer Kumar VB, Sudhakaran PR (2008): Modulation of angiogenic factors by ursolic acid. Biochem Biophys Res Commun 371: 556-560.

46. Roy S, Khanna S, Alessio HM, et al. (2002): Anti-angiogenic property of edible berries. Free Radic Res 36: 1023-1031.

47. Sohn KH, Lee HY, Chung HY, et al. (1995): Anti-angiogenic activity of triterpene acids. Cancer Lett 94: 213-218. 